\title{
Freedom by Reaching the Wooden World: American Slaves and the British Navy during the War of 1812.
}

\section{Thomas Malcomson}

Les noirs américains qui ont échappé à l'esclavage pendant la guerre de 1812 l'ont fait en fuyant vers les navires de la marine britannique. Les historiens ont débattu de l'origine causale au sein de cette histoire, en la plaçant soit entièrement dans les mains des esclaves fugitifs ou les Britanniques. L'historiographie a mis l'accent sur l'expérience des réfugiés dans leur lieu de réinstallation définitive. Cet article réexamine la question des causes et se concentre sur la période comprise entre le premier contact des noirs américains qui ont fuit l'esclavage et la marine britannique, et le départ définitif des ex-esclaves avec les Britanniques à la fin de la guerre. L'utilisation des anciens esclaves par les Britanniques contre les Américains en tant que guides, espions, troupes armées et marins est examinée. Les variations locales en l'interaction entre les esclaves fugitifs et les Britanniques à travers le théâtre de la guerre, de la Chesapeake à la Nouvelle-Orléans, sont mises en évidence.

As HMS Victorious lay at anchor in Lynnhaven Bay, off Norfolk, in the early morning hours of 10 March 1813, a boat approached from the Chesapeake shore. ${ }^{1}$ Its occupants, nine American Black men drew the attention of the sailors in the guard boat circling the 74 gun ship. The men were runaway slaves. After a cautious inspection, the guard boat's crew towed them to the Victorious where the nine Black men climbed up the ship's side and entered freedom. This scene would be repeated many times during the coming twenty-one months. American Blacks came individually and in both small and large groups seeking escape from slavery within the wooden hulls of the British Navy.

The plight of the former slaves sent to Nova Scotia in 1815-18 is well documented, and a rather disturbing tale in Canadian history. ${ }^{2}$ The story of the group

1 See Muster Table HMS Victorious entry 752-760, August-September 1813, National Archives of the United Kingdom (TNA), ADM 37/4182, and Captain's Log HMS Victorious, 10 March 1813, TNA, ADM 51/2936.

2 See Harvey Amani Whitfield, From American Slaves to Nova Scotian Subjects: The case of the Black Refugees, 1813-1840 (Toronto; Pearson Prentice Hall, 2005); H. A. Whitfield, "The Development of Black Refugee Identity in Nova Scotia 1813-1850," Left History 10 no.2 (Fall 2005): 9-31. Whitfield provides the latest and most thorough description of the Black refugees' experience in Nova Scotia. He re-writes the narrative established by earlier

The Northern Mariner/le marin du nord, XXII No. 4, (October 2012), 361-392 
deposited in Trinidad has been the heart of John Weiss' work on the group of refugees who volunteered for the Colonial Marine Companies. ${ }^{3}$ Frank Cassell, in 1972, saw the War of 1812 Black refugees as representing a rejection of slavery by the enslaved and as a sign that slaves were not as docile as slave owners had imagined. ${ }^{4} \mathrm{He}$ read significant agency in the actions of the escaping slaves, more so than he found in the British response to the ex-slaves. He did, however acknowledge the British use of runaway slaves to incite fears of insurrection in America. Christopher T. George re-wrote the story Cassell told, leaving the Black refugees as passive pawns of the British, who offered a bleak freedom in return for using them for military and political purposes. ${ }^{5} \mathrm{He}$ vividly contrasts the "loyalism" displayed by slaves who assisted in the defence of the United States, at Baltimore and New Orleans, with the position that the British either forced or enticed the Blacks to desert their masters. ${ }^{6}$

This paper examines the flight of the American Blacks from slavery by seeking

historians giving the refugees a more active role in shaping their experience. Whitfield debates the use of the terms loyalist and refugee which have been used in the literature to describe the escaping Blacks. He finds both limiting the agency of the ex-slaves and the context in which they found themselves. For views advancing less active agency on the part of the Black refugees see; James W. St. G. Walker, Racial Discrimination in Canada: The Black Experience (Ottawa: Canadian Historical Association, 1985). W. A. Spray, "The Settlement of the Black refugees in New Brunswick, 1815-1836." Acadiensis 6 no. 2 (Spring 1977): 64-79; John N. Grant, "Black Immigrants into Nova Scotia 1776-1815," The Journal of Negro History 58 no. 3 (July 1973): 253-270; and C. B. Fergusson, A Documentary Study of the Establishment of the Negroes in Nova Scotia between the War of 1812 and the Winning of responsible Government (Halifax: Public Archives of Nova Scotia, 1948). Also, J. S. Martell, Immigration to and Emigration From Nova Scotia 1815-1838 (Halifax: The Public Archives of Nova Scotia, 1942).

3 John Weiss, The Merikens: Free Black American Settlers in Trinidad 1815-16 (rev. ed.: London, 2002). Weiss, "The origins of the Merikens, the African Americans Who Settled Trinidad's Company Villages in 1816," retrieved from http://www.inmotionaame.org/texts/ ocr_text_print_all.cfm?id=4_027T\&page $=1$ \&anchor $=1$ and Weiss, "The Corps of Colonial Marines: Black freedom fighters of the War of 1812," retrieved from http://www.monishandweiss.co.uk/history/colonialmarines.html Weiss's work is without references and makes heavy use of secondary sources. For other work on the Colonial Marine Companies who settled on Trinidad see A. B. Huggins, The Saga of the Companies (Freeport, Trinidad: Twinluck Printing Works, 1978); B. Brereton, A History of Modern Trinidad 1783-1962 (Kingston, Jamaica: Heinemann, 1981); L. McDaniel, "Memory Spirituals of the Ex-Slave American Soldiers in Trinidad's 'Company Villages,"' Black Music Research Journal 14 no.2 (Autumn 1994): 119-143.

4 Frank Cassell, "Slaves of the Chesapeake Bay Area and the War of 1812," Journal of Negro History 57 (1972): 144-155, see 144.

5 Christopher T. George, "Mirage of Freedom: African Americans in the War of 1812," Maryland Historical Magazine 91 no.4 (Winter 1996): 427-450; C. T. George, Terror on the Chesapeake: The War of 1812 in the Bay (Shippensburg, PA: White Mane Books, 2000).

6 George, "Mirage," see 432, 439, for comments on British manipulation of Blacks and 441444 for the contribution by slaves to the defense of Baltimore and New Orleans. 
the protection of the British Navy during the War of 1812. It will explore the British response to the runaway Slaves from the point of first contact through to the removal of slaves from the American South in March 1815. The issue of agency is central to this story, for both the American Blacks who left slavery and the British who used the exslaves in their war effort against America. I will touch on the experience of the Black refugees aboard the British ships and how the British naval officers perceived them. An assessment will be offered of the impact of these runaway slaves on the war effort against the United States. An investigation more thorough than previous efforts into the number of American Blacks who fled slavery via the British during the war will indicate that past estimates are too low. Escaping slaves in the War of 1812 sought freedom in Chesapeake Bay, the vicinity of Cumberland Island (Georgia), New Orleans, and the contested border land of Spanish Florida.

\section{The War Begins and Admiral Warren's Instructions}

The first five months after the outbreak of war between America and Britain in June of 1812 witnessed an uncoordinated effort by the Americans to invade British North America. ${ }^{7}$ An American invasion at Sandwich, Upper Canada (now Windsor) in mid July was crushed by Major-General Isaac Brock in early August at the Battle of Detroit. The American incursion at Queenston Heights in mid October was repelled, though with the death of Brock. A third effort to invade, aimed at Montreal, in late November failed after an episode of "friendly fire" among the Americans, just inside the Lower Canada border with New York state. During the early months of the war, the British did not invade the American states or territories along the Canadian border (with the exception of Brock's foray at Detroit) as a result of British Governor-in-Chief Sir George Prevost's desire not to provoke the Americans in hopes that a quick peace might end the conflict. Perhaps the more important reason for Prevost's defensive stance was the limited number of regular troops in the upper province and its militia was only partially organized and its loyalty not certain. The British realized that if the Americans could launch a better led and larger invasion of Upper Canada the defenders would be hard pressed to hold the province. A diversion to draw American resources away from the border was needed.

The British Navy initially kept to the Atlantic. The Admiralty appointed Admiral Sir John B. Warren to command a combined North American and West Indies Station in August $1812 .{ }^{8}$ In December he was instructed to blockade the harbours and ports of

7 For a general overview of the war along the Canadian-American border and the first five months in particular see, John K. Mahon, The War of 1812 (Gainesville, FL: University of Florida Press, 1972); George Stanley, The War of 1812: Land Operations (Toronto: McMillan Canada, 1983); Robert Malcomson, A Very Brilliant Affair: The Battle of Queenston Heights, 1812 (Toronto: Robin Brass, 2003); Jonathon Riley, A Matter of Honour: The Life, Campaigns and Generalship of Isaac Brock (Montreal: Robin Brass Studio, 2011); Alan Taylor, The Civil War of 1812: American Citizens, British Subjects, Irish Rebels, \& Indian Allies (New York: Alfred A. Knopf, 2010).

8 Julian Gwyn, Frigates and Foremasts: The North American Squadron in Nova Scotia Waters 1745-1815 (Vancouver: UBC Press, 2003), 138. He had commanded along the North American coast from 1808 through 1810. 
Chesapeake Bay, and the Delaware River, in an effort to distract the American Government from sending troops to reinforce their continuing attempts to invade Upper Canada. ${ }^{9}$ Further instructions, issued in March 1813, addressed interactions with American slaves. ${ }^{10}$ Warren and his army counterpart, Colonel Sir Thomas Beckwith, were told they could remove any slave who assisted the British in any fashion and as a result were in danger of maltreatment from their masters, but they were under no circumstance to instigate a slave revolt, as "The Humanity which ever influences His Royal Highness must make him anxious to protect against a System of warfare which must be attended by the Atrocities inseparable from commotions of such a nature." ${ }^{11}$ More to the point the British Government was expressing the fear that such a "commotion" in America might cause a revolt within the British slave population in the West Indies. ${ }^{12}$ Britain had outlawed the slave trade in 1807 but did not release the slaves in the possession of British owners of West Indies plantations. The still recent (1791 to 1804) slave revolt on French held Saint-Domingue, which established the Republic of Haiti, was seared into the memories of all slave holders and their governments. ${ }^{13}$ Any activity that might promote another such revolt was to be avoided at all costs. The instructions went on to caution both officers to extend the offer of refuge only to those slaves who helped and to limit the number taken away. All slaves taken were to be regarded as free people and the government would be responsible for their maintenance. Lord Bathurst, secretary of state for war and colonies, suggested to Beckwith that some might even be willing to join His Majesty's Land or Sea Service. The instructions stressed a controlled approach to American slaves, featuring restricted contact. By the time these instructions reached Warren interaction with the Black slave population of America had already commenced and the words restricted or controlled could not be applied to what was taking place.

\section{First Contacts with American Blacks Escaping Slavery}

Sailing from Halifax for Bermuda in January 1813 Admiral Warren took his

9 Lords Commissioners of the Admiralty to Warren, 27 December 1812 in William S. Dudley, The Naval War of 1812: A Documentary History Vol. 11812 (Washington: Naval Historical Center, 1985), 633-634.

10 Croker to Warren, 21 March 1813, National Library of Scotland (NLS), Sir Alexander Cochrane Papers, MS 2326.

11 Bathurst to Beckwith, 21 March 1813, ibid.

12 The Bussa rebellion April 1816 on Barbados was inspired by the frustration of raised hopes that the act banning the Slave Trade in 1807 would lead to the emancipation of slaves. It is not know for sure if Barbados slaves were aware of the freeing of American Black slaves and their settlement as free people en masse in Trinidad and Nova Scotia, although it seems doubtful that they would not know. Parliament issued a Proclamation stating their shock at the slaves thinking that His Royal Highness had granted emancipation of the slaves and urged them to forget "those unfounded and dangerous impressions." Leith to Bathurst, 9 September 1816, TNA, CO 28/85. Leith is informing Bathurst that the proclamation had been read and posted throughout Barbados.

13 For the classic telling of the revolution see, C. L. R. James, The Black Jacobins: Toussaint L'Ouverture and the San Domingo Revolution (1938; London: Penguin Books 1980). 
squadron down the East Coast of America, passing the British blockade off Boston, Long Island, and the Delaware. Warren reached the mouth of Chesapeake Bay at the end of the month where he began to capture American merchant vessels and notified the Americans that the bay was under blockade. He left Captain George Burdett with a group of frigates to cruise off Lynhaven Bay, watching the American port of Norfolk and the United States Frigate Constellation at anchor there. Reaching Bermuda on 13 February, Warren found Rear-Admiral George Cockburn newly arrived from England whom he sent to Lynhaven Bay with four 74 gun ships and an 18 gun brig on the 18th. Cockburn anchored off Norfolk on 4 March $1813 .{ }^{14}$ Within a week slaves began to come out to the squadron seeking freedom, as in the account at the beginning of the present paper of the nine men who made their way to Victorious. Contacts with slaves increased in frequency during the first week of April as British shore parties began cutting out vessels, destroying American government stores, or foraging for food and water for the squadron. Lieutenant James Scott, on HMS Marlborough described these early contacts as not being clear as to which side the slaves were on, occasionally helping the British accomplish their mission and at other times warning the Americans of the British approach. ${ }^{15}$ The indecision Scott noted cut both ways. At times the British would promise the Americans that they would not carry away slaves. Royal Marine Major Marmaduke Wybourn told the people of the Island of Portsouci on 1 May 1813 that if their slaves drove the livestock down to the wharf the British would not take any slaves or other property away. ${ }^{16}$ At the end of May, Warren told Croker that, "sixty to seventy of these unfortunate people who escaped from their owners...are now in the several ships of the Squadron..." "impossible to refuse an asylum..." to the refugees.

True to the Admiralty's order of taking only those who helped, Warren reported offering refuge to a slave who had warned the British of a possible torpedo attack after the failed raid at Craney Island, in June $1813 .{ }^{18}$ In the same month, Captain Henry Byng, HMS Mohawk, accepted a "Black man" lent from HMS Boreas to serve as a pilot for the approaches to James River, where Byng was engaged in harassing the Americans. ${ }^{19}$ The Admiralty's instruction however had already been pushed aside, as from the beginning of May slaves began running towards the British as soon as they appeared in the

14 Warren's course can be followed in the HMS San Domingo's Log Book, 4 January 1813 through 18 February 1813. TNA, ADM 51/2834. Burdett to Warren, 9 February 1813. William S. Dudley, The Naval War of 1812: A Documentary History Vol. II (Washington: Naval Historical Center, 1992), 318, 320, Cockburn to Warren, 13 March 1813; Dudley. The Naval War of 1812: Vol. II, 320-324.

15 James Scott, Recollections of a Naval Life Vol. III (London: Richard Bentley, 1834), 77.

16 Emily Wybourn, Sea Soldier: An Officer of Marines with Duncan, Nelson, Collingwood and Cockburn The Letters and Journals of Major T. Marmaduke Wybourn RM, 1797-1813, A. Petrides and J. Downs, eds., (Tunbridge Wells, UK: Parapress Ltd., 2000), 181.

17 Warren to Croker, 28 May 1813, TNA, CO 37/71, 91. This copy was enclosed with Barrow to Goulburn, 31 September 1813, ibid., 89.

18 Warren to Meville, 23 June 1813, Library and Archives Canada (LAC), Orders for Adm. J. B. Warren, MG 34 F132, reel A-2076. The attack was on 22 June 1813.

19 Captain's Log HMS Mohawk, 30 June 1813, TNA, ADM 51/2595. 
neighbourhood. ${ }^{20}$ George Cockburn took in18 Blacks, who reached HMS Sceptre on 4 May1813, in between British raids on towns at the north end of Chesapeake Bay. ${ }^{21}$ Uncertain if he could keep the refugees, he wrote to Warren seeking direction. Warren allowed them to stay onboard. The key point in this episode is that these men had simply followed a foraging party as it returned to the ships, having provided no assistance to the British.

Soon entire families of slaves ran to the British. On 14 May five men, two women and three children came away from the mainland reaching shelter aboard HMS Dragon. ${ }^{22}$ Seven men made it out to HMS Fantome on 30 May. Two of them, Joshua Cormick and Jacob Silence, appear to have returned to shore and gathered their wives and children, returning to the Fantome on 3 and 8 June respectively. ${ }^{23}$ Captain Robert Honyman, HMS Marlborough, reported two black men, two women and a child came out to the ship on 11 July 1813, in Lynhaven Bay. Only four days earlier Warren had sent eight Black men, a boy, six Black women and four small children over to Honyman's ship after they had made their way to the San Domingo. ${ }^{24}$ Many of the American Blacks seeking freedom stole boats or canoes to reach the British ships, while some actually swam out; others escaped with the British shore parties.

The American paper Niles' Weekly Register reported the removal of "parcels of negroes" claiming several hundred slaves had been carried off by mid August $1813 .{ }^{25}$ The paper stated all were taken against their will, and were simply another form of stolen property the British were collecting along the shores of the Chesapeake. This image of passive slaves being forcibly carried away by the enemy was probably meant to ease the minds of slave owners, frightened by the thought of self-determining vengeful slaves joining with the British, rather than express the truth of the situation.

20 Scott, Recollections of a Naval Life, 115 and 118.

21 Cockburn's Journal, 4 May 1813, National Maritime Museum (NMM), Cockburn Journal, COC/11; Captain's Log HMS Dragon, 2 to 9 May 1813, TNA, ADM 51/2288. The British raided Havre-de-Grace and Fredericktown, and Georgetown on 3 and 6 May 1813, respectively.

22 The names appear in HMT Ruby's muster table giving the Dragon as the first ship they reached and the day appeared. For the five men see Muster Table HMS Ruby, entries 1853 to 1857, TNA, ADM 37/4099. The names of the women and children appear on the subsequent "Supernumeraries for Victuals Only" page and are not numbered. There are only first names as last names do not appear to have been recorded. The five men are listed as Landsmen.

23 The names appear in HMT Ruby's muster table giving the Fantome as the first ship they reached and the day they appeared. The muster table reveals when their wives and children boarded the Fantome. For the seven men see Muster Table HMT Ruby, entries 2008 to 2014, TNA, ADM 37/4099. The names of the women and children appear on the subsequent "Supernumeraries for Victuals Only" page is not numbered.

24 Captain's Log HMS Marlborough, 7 and 11 July 1813, TNA, ADM 51/2570; Captain's Log HMS San Domingo, 7, 11 and 12 May 1813, TNA, ADM 51/2834.

25 See articles from Niles Weekly Register, Vol. 4, March to September 1813, pp. 165, 182, 392, 423. 
The slave owners quickly followed the slaves out to the British ships in order to retrieve their property. Captains often allowed the slave owners to speak with their runaway slaves and try to talk them into returning to their former life. Most of the American Blacks refused the invitation. Captain Robert Barrie would let the owners aboard and wait by the gangway while someone was sent to ask the refugees if they wished to talk with them. ${ }^{26}$ When a negative response was returned the white slave owners would have to quietly endure the humiliation of being turned away, snubbed by a person they saw only as a slave, a mere piece of property. Warren hosted a Mr. Skinner, an Annapolis slave owner, aboard HMS San Domingo only to inform him upon inquiry that the people he spoke of were on their way to Bermuda. ${ }^{27}$ Rear-Admiral Cockburn allowed several local militia officers to come out to the Marlborough in early June 1813 to question the slaves aboard as to whether any would return with them. James Scott recalled that, "some quaint and home replies to these queries convinced the envoys of their loss of time in the attempt, and they took their departure." ${ }^{28}$ When a Lieutenant Colonel Addison sought to pay for the return of some former slaves he was told that it was "not the custom of the British Service to receive Ransoms" for people and that the "Black people... are at liberty to follow their own inclinations." 29 Slaves found onboard captured privateers, merchant or fishing vessels were "detained" and freed by the British. ${ }^{30}$ The Americans even claimed one group of these Blacks were prisoners of war and requested their inclusion in an exchange. Warren refused to entertain the idea. ${ }^{31}$

The number of slaves aboard the British squadron in the Chesapeake mounted quickly, producing accommodation and food problems. Admiral Warren wrote Lord Melville in early September 1813 asking him for direction in the dispersal of the over 300 men, women and children aboard the squadron. ${ }^{32} \mathrm{He}$ did not wait for a reply, ordering his captains to find all the Black men willing to work in the naval yard at Bermuda and send them there in HM Transport Ruby. ${ }^{33}$ Warren carried a small group of the ex-slaves north to Halifax with him when he returned to the port on 15 September. By 28 September at least 138 American Blacks were ashore and are often taken as the first group of War of

26 L. Gayle to Barrie, 9 and 10 March 1814, with Barrie's minute on back, William L. Clements Library, Robert Barrie File, Letters.

27 Report of Mr. Skinner, 1 September 1813, Gazette and Public Ledger Norfolk Virginia 10.14, p. 3.

28 Scott, Recollections of a Naval Life, 129-130.

29 Warren to Addison, 16 May 1813, TNA, ADM 1/503.

30 Perusal of the Prisoner of War exchange records in ADM 103/465, LAC, reel B-5349, reveals 24 men marked "Detained slaves," who were not returned with other men captured onboard the 10 vessels they were taken from.

31 Barrow to Warren, 9 July 1813, LAC, Admiralty Orders to the North American Station 18121815, ADM 2/933, reel B-3434.

32 Warren to Melville, 6 September 1813, LAC, Orders for Adm. J. B. Warren, MG 34 F132, reel A-2076.

33 Cockburn to All Officers, 25 September 1813, LAC, Talbot Letters Received Book 3, MG 40 MG 46, reel A-1632. 
1812 refugee Blacks to reach Nova Scotia. ${ }^{34}$ Actually, a group of ex-slaves were deposited at Halifax in mid July 1813, when Senior Officer Captain John Talbot instructed Captain John Lumly of Narcissus to send three Black females ashore, while granting permission to keep a group of Black males as "disposables." 35 Talbot had likely also sent ashore the fourteen male and one female American Blacks that had arrived on Victorious nine days earlier along with a group of American prisoners-of-war. ${ }^{36}$ This precedes the date given in the literature of first arrivals by nearly three months. It also poses the possibility that small groups of Blacks were deposited at Halifax even before July as ships from the Chesapeake arrived in Halifax for repairs and supplies. The 300 Warren referred to in September were all sent to Bermuda, Halifax or the Bahamas by the end of October. ${ }^{37}$ In October, Warren received guidance on disposing of the American Blacks. ${ }^{38}$ Those who provided service were to be settled in Nova Scotia or the West Indies and supported by the local government until they were self-sufficient. But the cat was out of the bag, the British in the Chesapeake were now committed to carrying away and resettling all Blacks who came to them, whether they helped or not.

34 Fergusson, 12, and fn 32. Fergusson cited 133 people being placed ashore on 28 September with reference to the Acadian Registrar for the arrival of ships from the Chesapeake on the 14th and the Nova Scotia Archives and Records Management, vol. 420, doc. 1-8 for the number of people discharged from each ship which adds up to 86 (Marlborough 43, Junon 20, Mariner 6, Fox 5, Diomede 52). The date of September 28 and total of 133 people has been repeated by many others studying the experience of the Blacks from the Chesapeake in the province. The 86 does not include several ships arriving from the Chesapeake including the San Domingo which discharged 52 people. 52 plus 86 is 138. Ships which do not have the number of Blacks sent ashore are Highflyer, Loup Cervier, Nemesis, Success, Diadem, Rifleman and Romulus. The people were put ashore between the 21st and 28th.

Talbot to Lumly, 17 July 1813, LAC, Talbot Letters Received Book 3, MG 40 M 46, reel A1632. Disposables equates to supernumeraries, men to be carried in the ship and used as the captain sees fit.

36 Victorious reached Halifax on 7 July 1813 and the following day the captain's log reports sending the prisoners-of-war ashore and receiving 54 men and officers who had taken prizes from the Chesapeake to Halifax. The 15 American Blacks listed in the Victorious' muster table do not appear in subsequent tables, although no information is given about their discharge from the ship. See Log Book HMS Victorious, 7 and 8 July 1813, TNA, ADM 51/2011; Muster Table HMS Victorious, April-May 1813, TNA, ADM 37/4181, see, Supernumeraries for Victuals only.

37 John Bassett Moore, History and Digest of the International Arbitrations to Which the United States has been a Party, Vol. 1 (Washington: Government Printing Office, 1898), see "Chapter XI, Difference as to the Treaty of Ghent: Award of the Emperor of Russia," 350390 , see 351 re sending ex-slaves to the Bahamas or other British possessions in the West Indies. Another source is the letters concerning the British investigation into American claims that runaway American slaves were sold back into slavery by British officers. This claim was proven false. See, Cameron to Cochrane, 9 May 1815, with enclosures, NLS, Sir Alexander Cochrane Papers, MS 2338.

38 Croker to Warren, 2 October 1813, with enclosure, LAC, Admiralty Orders to North American Station 1812-1815, ADM 2/933, reel B-3434. 


\section{Vice-Admiral Cochrane's Proclamation}

It did not take long before additional American Blacks replaced those sent away. Robert Barrie had another 120 men, women and children aboard HMS Dragon by midNovember, and was planning to immediately send 50 to Bermuda. ${ }^{39}$ The numbers of runaway slaves increased at the start of 1814 and climbed even higher after the new Station Commander-in-Chief Vice-Admiral Sir Alexander Cochrane issued his proclamation on 2 April 1814 offering to give "all those who may be disposed to emigrate from the United States..." the choice of serving in the British forces or being settled in a British Colony as "Free Settlers." ${ }^{40}$ While the term slave was not used in the proclamation the implication was clearly understood. Historians have compared Cochrane's proclamation with the one issued by Lord Dunmore, the Governor of Virginia in 1775, at the outset of the American Revolution. Dunmore did not intend to undermine the institution of slavery. His offer of freedom and land was to the slaves and indentured servants of the rebels only, in exchange for service in the British army, against the rebels. As Sylvia Frey notes he wanted to increase his forces and frighten the white rebels with the possibility of their slaves seeking retaliation. ${ }^{41}$ Unlike Lord Dunmore's proclamation of 1775, Cochrane did not make freedom dependent on serving in the British military or navy against the United States, but gave them choice. Dunmore's was not the only proclamation in the Revolutionary War that may serve as a comparison to Cochrane's. General Sir Henry Clinton, on 30 June 1779, announced that he would allow all Blacks captured in rebel service in his soon to begin southern campaign to be sold for the benefit of their captors, but that any Blacks who deserted from the rebels would be granted freedom to follow "any Occupation" they chose within British held areas, no military service required. ${ }^{42}$ While Cochrane's 1814 proclamation is a close match to Clinton's offer of freedom without military service, Cochrane was simply formalizing and encouraging what the British forces on the U.S. coast had been doing since April 1813, despite the Admiralty's instruction to take away only those slaves who offered assistance. Over a thousand copies were printed and sent ashore, left behind by British sailors and troops, or circulated by Blacks working with the British as informants. The American press helped spread the word by printing articles about the proclamation. ${ }^{43}$

39 Barrie to Warren, 14 November 1813, Dudley, The Naval War of 1812: Vol. II, 395-396.

40 Proclamation of Vice Admiral Sir Alexander F. I. Cochrane, RN, 2 April 1814, Michael Crawford, The Naval War of 1812: A Documentary History Vol. III (Washington: Naval Historical Center, 2002), 60. For a copy of Lord Dunmore's proclamation see http://www.blackpast.org/?q=aah/lord-dunmore-s-proclamation-1775.

41 Sylvia R. Frey, Water from the Rock: Black Resistance in a Revolutionary Age (Princeton: Princeton University Press, 1991), 63-64; Cassandra Pybus, Epic Journeys of Freedom: Runaway Slaves of the American Revolution and Their Global Quest for Liberty (Boston: beacon Press, 2006), 9; Simon Schama, Rough Crossings: Britain, the Slaves and the American Revolution (Toronto: Viking Press, 2005), 75-77.

42 Frey, 113-114, and Pybus, 40. Clinton's proclamation was issued ahead of his South Carolina campaign.

43 For example see Niles Weekly Register, vol. 6, 11 June 1814, 242. 
Tangier Island was used by the British as a base in the Chesapeake and served as a collection point for the runaway Slaves. ${ }^{44}$ The British sent the elderly and the women and children to Bermuda, Halifax or the West Indies, while the younger and fit males were encouraged to join the fight against the Americans. Many wanted nothing to do with the war, they were simply seeking freedom. The men who volunteered for service in the army or the special Colonial Marine Corps created in April 1814 were given the regular bounty for joining. Their wives and children, if they had either, stayed with them, and were provided for according to regulations governing troops abroad. ${ }^{45}$ The women and children were paid, if they worked at building fortifications on the island.

In May 1814 American efforts to stop the slaves from running began to have effect, enough to stir Cochrane to order raids to create havoc and encourage the desertion of slaves. ${ }^{46}$ The activity resulted in American Blacks running in even larger numbers in July and August, including many of the slaves at Calvert and St Mary's, and 135 who left with the British after their raid on Leonardtown. ${ }^{47}$ Problems quickly developed again concerning shortages of food, clothing and accommodation for the Black refugees. ${ }^{48}$ While some served as guides and others helped with building fortifications, many sat idle on Tangier Island. Cochrane sent most of those unwilling to work or join the fight against America to Halifax, with a few going to Trinidad. ${ }^{49}$

The British Government ordered more troops to the North American Station in mid 1814 to to intensify the raids along the Chesapeake shore. In the orders to MajorGeneral Edward Barnes, the officer originally designated to lead the troops, Bathurst gave the same direction that he had given Beckwith in 1813: carry away slaves who helped, take only a few and do not encourage in any way a more general uprising of the American Blacks. ${ }^{50}$ Bathurst also again noted the danger that such a revolt in the United States might trigger violence in the British slave plantations in the West Indies. MajorGeneral Robert Ross, who came out from England to take up the Chesapeake command in place of Barnes, brought the orders with him. ${ }^{51}$ Ross arrived in July, in the midst of Cochrane and Cockburn's redoubled efforts to remove as many slaves as they could

44 Cockburn to Warren, 13 April 1814, Crawford, The Naval War of 1812: Vol. III, 46-49. Cockburn tells of sending several Black men back into the countryside close to Tangier Island to inform the slaves that the British would take away any who reach the island. Tangier Island was chosen because it provided a good anchorage, close to shore, could supply fresh water and was thought easy to defend.

45 Cochrane to Prevost, 11 March 1814, ibid., 38-40.

46 Cochrane to Cockburn, 27 May 1814, ibid., 69-70.

47 Nourse to Cockburn, 23 July 1814, ibid, 159-160 and Cockburn to Cochrane, 21 July 1814, ibid., 163-166. The Leonardtown raid was on July 19.

48 Cockburn to Cochrane, 2 April 1814. Crawford, ibid., 40-42; Cockburn to Warren, 27 April 1814, ibid., 50-51.

49 Cochrane to Cockburn, 28 April 1814, ibid., 51-52.

50 Bathurst to Barnes, 20 May 1814, ibid., 72-74.

51 Ross replaced Barnes who was with Wellington's staff in the Peninsula; see Crawford, The Naval War of 1812: Vol. III, 74. 
whenever they conducted a raid, and to accept everyone who reached the British ships. Thus, as with the earlier orders to Beckwith and Warren, the new iteration with Ross arrived in circumstances that made them irrelevant. The only element of Bathurst's instructions that the local commanders applied was the prohibition against starting a slave revolt. The fact that the British forces, after their attack on Washington, did not bring away a significant number of Blacks with them has been cited as evidence that the British removed the Blacks only when it suited them. That in turn suggests the Black people had little control over their own escape. ${ }^{52}$ The evidence is drawn from George Cleig's narrative of the events during the British retreat from Washington: "During this day's march we were joined by numbers of negro slaves, who implored us to take them along with us, offering to serve as soldiers or sailors, if we would but give them their liberty; but as General Ross persisted in protecting private property of every description, few of them were fortunate enough to obtain their wishes." ${ }^{53}$

Ross's primary concern was to get his exhausted troops back to the ships before the Americans could counter attack. Encumbering his column with a mass of refugees would slow the retreat and make the re-embarkation much more difficult resulting in an unacceptable increase in his vulnerability to attack. The salient point in Cleig's comment is that Ross regarded the Blacks as private property, a concept seemingly abandoned by other British officers who helped them to escape and allowed them free choice when their former masters tried to convince them to return. Perhaps Ross was influenced by his instructions to limit the numbers carried away. Killed soon after in the assault on Baltimore, Ross was unable to respond to Cleig's later remarks on the Washington retreat.

American Blacks did in fact escape slavery with the British raid on Washington and the simultaneous naval assault on Alexandria. ${ }^{54}$ Abraham Davis, working in the Washington Naval Yard at the time of the attack, joined the British withdrawal from the American capital. ${ }^{55}$ Stephen Allen helped British Troops carry off barrels of flour at Alexandria and then left with them. ${ }^{56}$ Slave owners Charles and Ursula Bowie claimed three of their slaves, Osburn, Dan, and Toby went off with the British as they passed through Upper Marlborough on 27 August. ${ }^{57}$ Benjamin Allen and John Hodges reported a total of five slaves ran as the British passed through Upper Marlborough on their way down the Potomac after the raid on Alexandria and went with them, leaving his master

52 George, Terror in the Chesapeake, 112-113.

53 George R. Cleig, The Campaigns of the British Army at Washington and New Orleans (1879; Charleston, SC: Bibliobazaar, 2007), 96

54 During the attack on Washington, Captain James Gordon led a British squadron of ships up the Potomac River and seized Alexandria.

55 RG76 Records of the Domestic Claims Commission Case Files, Ca. 1814-28, (hereafter Domestic Claims) Boxes 1 through 10, United States National Archives and Records Administration (NARA), Box 8, Claim 766 by Edward Davis, affidavit by John Wilkins 22 April 1828.

56 Ibid., Claim 729 by Henry Dangerfield, affidavit by John Lindsey 15 February 1828.

57 Ibid., Claim 752 by Charles and Ursula Bowie, affidavit by (same) 16 September 1821. 
back to the embarkation point. ${ }^{58}$ Isaac, another slave, saw the British ships returning Thomas Maccubbin. ${ }^{59}$ Ross may have refused the requests of large group(s), but American Blacks still escaped with the British during and after the attack on Washington, individually and in small groups.

The main British force left Chesapeake Bay in October to begin preparations for the attack on New Orleans. A squadron was left in the bay to continue the blockade, conduct raids and receive slaves on Tangier Island. Even at the end of the war slaves continued to come out to the island seeking freedom. All who had reached the island by 11 am on 17 February 1815 (the time of the American ratification of the Treaty of Ghent) were taken away in March when the British returned the island to the Americans. ${ }^{60}$

\section{West and East Spanish Florida}

Another area where the British attempted to encourage American Blacks to flee slavery was in West and East Florida, which was then a Spanish possession. Spain was allied with the British in the war against France but was trying to remain neutral in the war with America. The Creek Indians inhabited the large wilderness that lay between the American settlements in the Mississippi Territory (which included the present state of Alabama) and those in the state of Georgia and the border of Spanish Florida. American interest in the lands occupied by the Creek Indians led to a war waged between July 1813 and March 1814 that ended with the Creek surrender of twenty-three million acres of territory. ${ }^{61}$ Those events fractured the Creek nation; some signed the treaty with the United States while others (particularly the Red Sticks) fled to Spanish Florida and sought help from the British to continue the fight against the Americans.

58 Ibid., Claim 728 by Benjamin Allen claims four slaves while Claim 798 by John Hodges claims one slave fleeing with the British at Upper Marlborough.

59 Ibid., Claim 771 by Thomas Maccubbin, affidavit by John Oden 23 August 1824.

60 Clavell to Cockburn, 23 February 1815, Crawford, The Naval War of 1812: Vol. III, 349; Cockburn to Clavell, 10 March 1815, ibid., 350. Cockburn ordered Clavell to take all the Blacks who wanted to leave and had come out to the island by the 17 February. He even gave $11 \mathrm{am}$ as the cut off time when deciding if their appearance was prior to the ratification.

61 For a description of the Creek War and British activity in the Gulf coast area during the War of 1812 see John Sugden, "The Southern Indians in the War of 1812: The Closing Phase," The Florida Historical Quarterly 60 no.3 (January 1982): 273-312; Nathaniel Millett, "Britain's 1814 Occupation of Pensacola and America's Response: An Episode of the War of 1812 in the Southeastern Borderlands," The Florida Historical Quarterly 84 no.2 (Fall, 2005): 299-255; Frank L. Owsley, Jr. Struggle for the Gulf Borderlands: The Creek war and the Battle of New Orleans 1812-1815 (Gainesville, FL: University of Florida, 1981); H.S. Halbert and T. H. Ball, The Creek War of 1813 and 1814 (Chicago: Donohue \& Henneberry, 1895). The Treaty of Fort Jackson ending the Creek War was signed on 9 August 1814, by which time the Indians who had sought refuge in Spanish Florida had begun receiving assistance from the British to continue the fight. A longer view of the borderland between the young American nation and Spanish Florida can be found in Gene A. Smith and Sylvia L. Hilton, Nexus of Empire: Negotiating Loyalty and Identity in the Revolutionary Borderlands, 1760s-1820s (Gainesville, FL: University Press of Florida, 2010). 
In 1814 the British sent Jamaican merchant George Woodbine (known to the Creeks) with a brevet rank of lieutenant in the Royal Marines and Royal Marine Major Edward Nicolls to gather and organize the estimated two to three thousand Creek Indians who had sought refuge in West and East Florida. This force would be employed to secure the West Florida area as a base for British operations against New Orleans and up the Mississippi River. ${ }^{62}$ Prior to the war and before the British arrived in 1814 American Blacks had escaped slavery by running into the areas where the Creek lived and into the northern section of Spanish Florida. Living in independent Maroon communities among the Black Seminoles or with the Creek, many of these Blacks fought alongside the Indians against the Americans in the Creek War. ${ }^{63}$

The exact number of American Blacks who escaped slavery after August 1814 in response to Nicolls' and Woodbine's mission is unknown. Many of them came into the British held areas with the much larger numbers of Indians that flocked to the British enoys. At the war's conclusion some stayed near the British fort at Prospect Bluff, some lived among the Indians, while others may have settled along the Suwannee River. ${ }^{64}$ In May 1815 Bermuda Governor James Cockburn wrote an unknown correspondent that HMS Carron, wiht176 American and Spanish former slaves on board, was headed for Nassau and Bermuda from Appalachicola. ${ }^{65}$ Certainly some were sent to Trinidad. ${ }^{66}$ Only twenty-three males, eight women and twelve children said to be former American slaves reached Bermuda from Florida at the conclusion of the war. ${ }^{67}$

62 Woodbine arrived first, in May 1814 with Nicholls being assigned by Cochrane in July 1814 arriving in Apalachicola the following month. The two men seem to have worked well together. Shortly after their arrival Nicolls was made a brevet Colonel and Woodbine a brevet Captain. See Owsley, 98 and Millett, 230.

63 Toni Carrier, "Black Seminoles, Maroons and Freedom Seekers in Florida, Part 2: The Beginning of Troubled Times," (2005) http://www.africanaheritage.com, and Patrick Riordan. "Finding Freedom in Florida: Native Peoples, African Americans, and Colonists, 1670-1816," The Florida Historical Quarterly 75 no. 1 (Summer, 1996): 24-43.

64 Sugden, 295. The fort was known variously as Fort Nicholls, the British Fort, and the Negro Fort.

65 J. Cockburn to unknown, 21 May 1815, Domestic Claims, NARA, Box 8, Claim 783 by Louis Dolives.

66 Weiss, The Merikens.

67 The numbers are from Lewis to Commissioners of His Majesty’s Navy, 28 June 1822, TNA, CO 37/81, 268. This group appears to have worked in the Naval Yard, earning wages nearly on par with "English Laborers" and becoming self-sufficient. They did however cause problems for the naval yard officials, who in 1821 were looking to either send them back to their American slave masters, or to Trinidad and if neither of these options worked to be able to administer corporal punishment to bring them back to obedience. The problem appears that they were demanding and argumentative. See John Lewis to Goulburn, 20 November 1821, and Lewis to Navy Office, 9 November 1821, TNA, CO 37/80, 4, 5 and 8-10 respectively. They were sent to Trinidad in 1822, William Leith to B. Wilmot, 15 June 1822, TNA, CO 37/81, 262. 


\section{New Orleans and Cumberland Island}

In late 1812 Admiral Warren ${ }^{68}$ proposed capturing New Orleans with 3,000 troops and holding it with an army raised from local ex-slaves freed by the British. ${ }^{69}$ The plan was rejected at the time but not completely forgotten. Warren's replacement, ViceAdmiral Cochrane, came to North America with the idea of raising an Indian army in West Florida that would ultimately attack New Orleans. ${ }^{70}$ The British Government favoured an attack against the city by British regulars. In the fall of 1814 Cochrane adopted the government's approach and sailed south in November to gather the invasion force at Port Royal, Jamaica. With news that General Andrew Jackson had left New Orleans and had captured Mobile, and that the Americans were aware that New Orleans was a target, Cochrane quickly left Jamaica in late November to strike at what he thought would be an easy target.

The British arrived at the anchorage between Ship Island and Chandeleur Island, some 96 kilometres from New Orleans on 8 December. They secured Lake Borgne as a route along which to transport the troops to New Orleans, after a lengthy chase and costly engagement with the small American flotilla holding the lake. The landings began on 17 December as the men of the British squadron ferried the troops (during the course of the campaign over 10,000 men, 24 cannon and all their necessary supplies) via Lake Borgne and the Bayou Bienvenue to a landing spot 14 kilometres south of the city. The British Army formed its position on several plantations, including that of American Major General Jacques Villeré. From 23 December through to the major engagement on 8 January the opposing forces did battle four times. The British defeat on the $8^{\text {th }}$ lead to a retreat between the $18^{\text {th }}$ and $23^{\text {rd }}$, with the navy rowing the surviving troops back to the awaiting squadron.

During this quick withdrawal 222 American slaves joined the British sailors and army in their retreat to the Gulf of Mexico and re-embarkation. ${ }^{71}$ Slave owners or their agents followed the British to Dauphin Island seeking the return of the Blacks. While 18 did return, the Americans found the British less then helpful. In some cases ship masters stopped the owners from boarding ships. Captains kept the slaves hidden below deck, while the Blacks still ashore kept inside the tents the British gave them for shelter so as not to be identified by their former masters. Despite the Treaty of Ghent's first paragraph, which required the British to return all property and slaves taken, the British officers refused to send back any person who did not wish to return. Two hundred and four

68 For more detail on this campaign see, Robin Reilly, The British at the Gates: The New Orleans Campaign of the War of 1812 (New York: G. P. Putnam's Sons, 1974); Owsley, Struggle for the Gulf Borderlands; Wilburt Brown, The Amphibious Campaign for West Florida and Louisiana, 1814-1815: A Critical Review of Strategy and Tactics at New Orleans (Tuscaloosa, Alabama: University of Alabama Press, 1969).

69 Warren to Melville, 18 November 1812, NMM, Warren Papers.

70 Owsley, 134.

71 See Slave Evaluation Report circa 1825, Williams Research Centre (The Historic New Orleans Collection) [WRC], Mss.199. 
American Blacks from New Orleans were sent to Bermuda before being forwarded to Trinidad. $^{72}$ As the American Blacks were taken aboard the British ships Rear-Admiral Edward Codrington ordered all Blacks, both ex-slaves and troops in the West Indies Regiment (composed of Black troops), shipped in transports separate from the white troops, in part to encourage enlistment of the newly freed. ${ }^{73}$

As Cochrane carried the British Army to New Orleans he ordered the seizure of Cumberland Island, off the coast of Georgia, in an effort to divert American forces away from New Orleans, and impede the American use of Georgia lumber milled at St. Simon (opposite Cumberland Island) in the construction of its naval vessels. A British squadron under Captain Robert Barrie (Cockburn arrived later) appeared off Cumberland Island at the end of December making the landing on 10 January (after the British defeat at New Orleans). ${ }^{74}$ The British easily captured the island and raided settlements along the adjacent Georgian coast. In order to encourage slaves to run the invaders used the Colonial Marines and two companies of the West Indies Regiment. ${ }^{75}$ The Colonial Marines were made up of recently freed American Blacks, while the West Indies Regiment (established in 1795) was constituted from West Indies and African slaves. Once again slaves came to the British in large numbers, from which Cockburn predicted another 200 volunteers for the Colonial Marines would be gained. The Treaty of Ghent required the British to return Cumberland Island to the United States. At the beginning of March 1815 the British departed from the island taking with them 1,483 Black refugees. ${ }^{76}$ Cockburn was forced to leave behind approximately 75 slaves who had come out to the British after the ratification date. ${ }^{77}$

\section{The American Blacks in "His Majesty's Sea and Land Services"}

The Black refugees afforded the British means to strike at the Americans. Some led the British on raids of their former masters' farms, some returned to shore to encourage other slaves to run. When the British needed horses for the reinforcements

72 Power to Claiborne, 30 March 1815, ibid. Major-General John Power was left in charge of British forces after General Lambert left the area.

73 Codrington to Delafour, 25 January 1815, LAC, MG 24 F 131, Sir E. Codrington fonds, reel A-2076.

74 See Mary Bullard, Black Liberation on Cumberland Island in 1815 (DeLeon Springs, FL: E. O. Painter Printing Co., 1983); Owsley, 135-136.

75 For a history of the West Indies Regiments see Roger N. Buckley, Slaves in Red Coats: The British West Indies Regiments, 1795-1815 (New Haven, CT: Yale University Press, 1979).

76 Bullard, 102. She arrived at this number by counting the supernumeraries carried aboard the ships off Cumberland Island at the time of their departure. These lists can be found in Documents furnished by The British Government under the Third Article of the Convention of St Petersburg, 30 June, 12 July 1822 and Baly's List of Slaves and of Public and Private Property, remaining On Tangier Island and on Board H.B.M. Ships of War after the Ratification of the Treaty of Ghent (Washington: Gales and Seaton, 1827). See also Pinckney to Secretary of War, 18 March 1815, NARA, Domestic Claims, Box 8 Claim 783 by Louis Dolives. Pinckney states that over 1000 slaves left with the British. Bullard, 93. 
coming from Europe in 1814 they paid runaway slaves $\$ 20$ for each horse they brought with them although the number of horses obtained through the scheme is unknown. ${ }^{78}$ The British, as we have seen, also hoped that many would join the army, particularly the West India Regiment, or enter the navy.

The muster tables of British ships in the Chesapeake reveal that some of the American Blacks entered into the navy as landsmen. ${ }^{79}$ The nine that came out to the Victorious on 10 March 1813 all did. Some American Blacks served in carpenter's and sailmaker's crews and a few became servants to the officers. ${ }^{80}$ Those who served afloat appear to have done so for only a short time; all those thus far located in ships' muster tables were discharged to Bermuda in fairly short order ${ }^{81}$ The nine on Victorious served the longest, seven months. As noted above Captain Talbot instructed Captain Lumly of Narcissus to enter eleven male Chesapeake ex-slaves into the books as "disposables." 82 Nine days later he ordered Lumly to send two of the former slaves to serve on HMS Pictou as "disposable Black Slaves." table transferred from HMS Dragon and entered as "landsmen". Perhaps they had served in this lowest of seamen's rating, helping to haul on lines, carry and clean, until Captain Barrie could send them off to Bermuda. The number of Black refugees formally entering the navy as seamen appears small and quite possibly they did so only temporarily, filling spots in the muster table until British sailors could be secured. Some perhaps served for their victuals and/or some pay to support themselves while awaiting transportation to a British colony.

Major Ross, commanding the Second West India Regiment noted in June 1814 his intention to recruit from among the refugee Blacks at Bermuda ${ }^{84} \mathrm{He}$ lamented being 300 men short and that the abolition of the slave trade had ruined recruitment for the regiment. With Cochrane's support he hoped to fill his ranks, but the American Blacks preferred settlement in a British colony or entry into the Colonial Marine Corps, which was created in 1814 specifically for American Blacks, over service in the West Indies

78 Cochrane to Cockburn, 1 July 1814, Crawford, The Naval War of 1812: Vol. III, 129-130.

79 The signs of this would be, place of birth (America), the indication they were "American Blacks," "Virginia Slaves" or "American Slaves who deserted from the American coast" as that is how they were entered as supernumeraries for victuals when they arrived aboard ship and when placed within the ship's muster table's main section. Also of help in determining their place of origin is the indication of where (Virginia, Cumberland Island, etc.) and when they entered the ship (the time corresponds to the ship or a detachment of its crew being there).

80 Allan Taylor, 2011, personal communication.

81 Five escaped slaves listed in the Ruby's Muster Table, transferred from HMS Dragon and were listed as "Landsmen".

82 Talbot to Lumly, 17 July 1813, LAC, Talbot Letters Received Book 3, MG 40 M 46, reel A1632.

83 Talbot to Lumly, 26 July 1813, Ibid.

84 Ross to Cameron, 11 June 1814, NLS, Sir Alexander Cochrane Papers, MS 2338. 
Regiment. ${ }^{85}$ Men serving in the Colonial Marine saw themselves as superior to the Blacks among the West Indies Regiment, an opinion shared by Colonial Marine officers. During preparations for the assault on Cumberland Island officers from the light companies of the West Indies Regiment were sent to train the Colonial Marines in "light movements". The men became highly agitated believing that they had been transferred to the other regiment. ${ }^{86}$ James Cockburn, Governor of Bermuda stated, "no incentive would get them to indiscriminately mix or enlist themselves in the West Indies Regiment." ${ }^{\prime 77}$ It appears very few if any American Blacks entered the West Indies companies. Others may have joined other army regiments but the difficulty in tracking them through the musters makes it nearly impossible to even guess at the number, though it was certainly not many.

The idea to create a special corps from the American Blacks had been suggested a number of times. Cochrane posited the idea in April 1812 when he suggested that war with America should be waged in the Chesapeake and against the cities (such as Washington and New Orleans) ${ }^{88}$ In the Chesapeake slaves could be encouraged to desert their masters and formed into an army to fight their former masters. Cochrane realized the threat of a full scale insurrection would contribute significantly to the British cause. Captain James Stirling suggested to his uncle Vice-Admiral Charles Stirling, commanding at Jamaica, that a body of Black troops in the New Orleans area would cause panic since the local whites had been experiencing problems with their slaves. ${ }^{89}$ Lieutenant-Colonel Charles Napier offered to raise, train and lead an army of freed slaves from Virginia and march them against Washington. ${ }^{90}$ Admiral Warren and Colonel Beckwith also offered the idea to Lord Melville in early 1813. Warren noted the panic created in the Americans once their slaves began to run to the British. ${ }^{91} \mathrm{He}$ reported that rumours abounded among the Americans of Blacks gathering at night to practice how

85 Cochrane to Bathurst, 11 July 1814, Crawford, The Naval War of 1812: Vol. III, 131-132.

86 Kinsman to J. Cockburn, 10 August 1815, TNA, CO 37/73, 58.

87 J. Cockburn to Torrans, 23 August 1815, ibid., 52.

88 Roger Morriss, Cockburn and the British Navy in Transition: Admiral Sir George Cockburn 1772-1853 (Columbia: South Carolina: University of South Carolina Press, 1997), 97-98. A copy of this statement is held by the Hull History Centre, Hull, U.K.,(HHC) under the title "Book of Remarks - suggesting ways and means of attacking America in the event of war" among the Sir Henry Hotham Collection, UDDHO 7/99. It is dated 1813, but the content indicates it clearly predates that year. There is no signature on the document.

89 Stirling to Stirling, 15 November 1812, HHC, Hotham Collection, UDDHO 7/13. This letter was relayed to Warren by Vice Admiral Stirling the day Stirling received it. Captain Stirling sent a similar letter to Lord Melville, 17 March 1813, The Historical New Orleans Collection (http://www.hnoc.org).

90 W. Napier, The Life and Opinions of Sir Charles James Napier Life and Opinions, Vol. 1 (London: John Murray, 1857), 369-370, also cited in George, Terror, 169-170. This plan was completely unrealistic. He proposed to go ashore with 100 officers experienced in training Black troops and one regiment. He promised to deliver 100,000 Blacks fully trained in a week. The fact he did not hear back from "the authorities" to whom he sent his plan is not surprising.

91 Warren to Croker, 28 May 1813, TNA, CO 37/71, 91. 
they would attack their masters.

The order to establish a regiment of the Black American ex-slaves originated with Sir Alexander Cochrane in early $1814 .{ }^{92}$ Cochrane ordered Rear-Admiral Cockburn to collect runaway slaves at the British base on Tangier Island in the Chesapeake for entry into a body of Black troops. Vice-Admiral Cochrane's April proclamation was to assist in raising volunteers. Cochrane wrote Bathurst in July asking for a thousand "sets of dragoon Acoutrements" as he expected at least that number of former slaves, all expert horsemen in his opinion to rise up and join British forces. ${ }^{93}$

At first, George Cockburn was less then encouraged by the idea. He told Warren in April that he had about fifty Black men helping with the defensive works at Tangier Island. ${ }^{94}$ They would be trained as a body of troops when the defences were further along. He didn't expect that the number Warren predicted would appear until a major landing ashore convinced the Blacks of British superiority. Upon hearing of Cochrane's proclamation Rear-Admiral Cockburn was disappointed that it did not require the Blacks to serve the Crown before receiving freedom, and suggested he would play down the element of choice when recruiting. ${ }^{95}$ Cockburn's first opinion of the American Blacks as fighters was negative, "Blacky hereabouts is naturally neither very valorous nor very active." 96 At the start of May he reportedly had 78 soldiers training for the "Black Corps." 97 In the muster table for the corps only 46 men were listed by the end of May, with 32 more names added in mid June. The Colonial Marines were combined in September 1814 with the remnants of the $3^{\text {rd }}$ Battalion of Royal Marines to form the $3^{\text {rd }}$ Battalion of Royal and Colonial Marines. By 10 December, 289 American Blacks constituted three companies in the battalion. They had experienced eighteen dead, four missing and three desertions from their base on Tangier Island. ${ }^{98}$ A fourth company of 62 American Blacks was added in December, but due to a series of deaths (explained below) the effective number of the four companies was only 318 at the start of 1815 . As noted above another 200 men were predicted to be added to the companies from Cumberland Island. When the ships left Cumberland Island in March 1815, with the war over, Regulus carried 378 men labelled as members of the Colonial Marines, a mere 60 additional men. ${ }^{99}$

92 Morris, 98.

93 Cochrane to Bathurst, 14 July 1814, Crawford, The Naval War of 1812: Vol. III, 131-132.

94 Cockburn to Warren, 13 April 1814, ibid., 46-49.

95 Cockburn to Cochrane, 2 April 1814, ibid., 43-46.

96 Cockburn to Cochrane, 2 April 1814, ibid., 44.

97 Cockburn to Cochrane, 9 May 1814, Ibid., 61-63. The number rose to 120 by mid July, see Cockburn to Cochrane, 17 July 1814, ibid., 154-157.

98 See Muster Tables for the seven companies of the 3rd Battalion of Royal and Colonial Marines, 4 April through 31 December 1814, TNA, ADM 96/341. The first three companies were the remnants of the 3rd Battalion of Marines while the last four were the American Blacks in the Colonial Marines.

99 Weiss notes that 407 men were discharged from the Colonial Marine at Bermuda in 1816, Weiss, The Merikens, 24. This number represents those that survived the war and those added 
The first raid involving the Colonial Marines was at Pungoteague ( Pungoteake), Virginia , on 29 May 1814, in which one of their members was killed. ${ }^{100}$ In June, 30 Colonial Marines participated in raids at St. Jerome's Creek, and along the Patuxent River. ${ }^{101}$ Their first major action was at Bladensburg on the way to Washington, on 24 August, followed by the Battle of North Point, at Baltimore, on 12 September. ${ }^{102}$ The British officers leading them praised the Blacks as being disciplined under fire, with an eagerness to engage the enemy. Even Cockburn changed his opinion, stating they were "getting on astonishingly, and are really very fine Fellows...they have induced me to alter the bad opinion I had of the whole of their Race \& I now really believe these we are training, will neither show want of Zeal or Courage when employed by us in attacking their Old Masters." ${ }^{103}$ At the war's end they were taken to Bermuda and served as the Naval Yard detachment. They were described in mid 1815 as a small, but close knit group, trusting their officers and holding the British to their promises regarding freedom and support for having fought during the war. ${ }^{104}$ With the disbanding of their battalion the Colonial Marines and their families were settled in Trinidad in $1816 .{ }^{105}$

Cochrane had given Nicolls orders to raise a Battalion of Black troops from the hundreds that they anticipated would flee American slavery when Cochrane's proclamation was distributed across the plantations in southern Georgia and the Mississippi Territory. ${ }^{106}$ Some of the Black Americans who had fled slavery before 1814 fought with the British, but as independent fighters much like the Indians; they did not join a Black battalion. ${ }^{107}$ The battalion Nicolls established was constituted largely of Red Sticks. ${ }^{108}$ The issue of how many American Blacks volunteered for military service is clouded by the tendency that Nicolls and Woodbine had of accepting the requests for freedom from the slaves of their Indian and Spanish allies. For six months' military service any slave it appears could be freed, a local variation on Cochrane's proclamation.

to the battalion from Cumberland Island after the war's end.

100 Cockburn to Cochrane, 25 June 1814, Crawford, The Naval War of 1812: Vol. III, 117-120.

101 For St Jerome's Creek see, Barrie to Cockburn, 1 June 1814, ibid., 77-78. For the Patuxent see Barrie to Cockburn, 19 June 1814, ibid., 111-114.

102 Cockburn to Cochrane, 27 August, 1814, ibid., 220-223.

103 Cockburn to Cochrane, 10 May 1814, ibid., 63-65, see 65. At the same time Bathurst was reminding Major General Edward Barnes not to foment a slave insurrection, only take slaves who assisted the British cause, see, Bathurst to Barnes, 20 May 1814, ibid., 72-74.

104 J. Cockburn to Torrans, 23 August 1815, TNA, CO 37/73, 54b. At the end of the war the three companies of British troops in the Battalion were sent home and the remaining 'Black' companies were renamed the Third Battalion of Colonial Marines, see Weiss, The Merikens, 10.

105 Donald Hickey, Don't Give Up the Ship! Myths of the War of 1812 (Toronto: Robin Brass Studio, 2006), 190. Hickey refers to the creation of six companies during the war but only four were developed by the end of the war.

106 Cochrane to Nicolls, 4 July 1814, TNA, ADM 1/506, 480-85.

107 Millett, 245-250; Sugden, 293.

108 Millett, 236 and 245, Nicolls began training his Battalion in August 1814, at which time it consisted of 500 Indians and possibly 100 Blacks. 
In one incident George Woodbine took away fourteen slaves requesting refuge from an ally Indian chief. ${ }^{109}$ Nicolls took forty-five slaves from John Innerarity, a Pensacola resident to serve in the British forces at Prospect Bluff. ${ }^{110}$ Woodbine freed so many Spanish slaves that in 1815 he was arrested for "appropriating slaves." ${ }^{111}$ From Pensacola and Apalachicola alone, Nicolls and Woodbine freed 665 slaves belonging to the Spanish between August 1814 and March 1815. ${ }^{112}$

Cochrane later stated that 300 to 500 Black troops were raised in Florida during the war and would be added to the Colonial Marines raised in the Chesapeake. Writing at Bermuda in 1816, Royal Marine Major A. Kinsman remarked how Cochrane had inflated the numbers and that few, of what were then referred to as the Florida Blacks, were ever assembled into a military unit. ${ }^{113}$ Another indicator of the failure to entice large numbers to join a Black battalion is the fact that Nicolls made only passing reference to the task of raising such a unit in his post war memorial, while spending significant space on his work with the Creek Indians. ${ }^{114} \mathrm{He}$ cited the specific numbers and activities of the Indians recruited but made no statement on the number or activities of any American Blacks collected. Perhaps Cochrane inflated the numbers of Blacks willing to serve in a Colonial Marine in order to preserve the battalion after the war as a potential weapon against the United States in any future conflict.

It is impossible to say exactly how many American Blacks escaped slavery by running to the British in Florida. Those who did not leave with the British or escape to the Bahamas or Jamaica or elsewhere in the West Indies were either killed or taken back

109 The story, "From Nassau..." appears in the London Times, 7 November 1815, Issue 9672, 4, col. B. Nicolls apparently had negotiated a different arrangement with Blacks who served in the Colonial Marine Companies he created, dismissing them from service as soon as the war concluded. The American Blacks from the Chesapeake who entered the Colonial Marines, on the other hand weren't discharged until 1816, when the Battalion was disbanded.

110 "Documents Relating to Colonel Edward Nicolls and Captain George Woodbine in Pensacola, 1814," The Florida Historical Society Quarterly 10 no.1 (July, 1931): 51-54, see 53.

111 Sugden, 295.

112 Relacion delos Negros pertenecientes á los habitantes dela Plaza Panzacola que se han fugado y llevado los Ingleses á Apalachicola, 4 March 1815, NLS, Cochrane Papers MS $748 / 73,77$. This and other requests to return Spanish slaves to their masters were rejected by the British. For example see Cochrane to Manrique, 10 July 1815, Documents Relating to Colonel..., 52.

113 Kinsman to J. Cockburn, 10 August 1815, TNA, CO 37/73, 58b. Millett, 247-250, His description of the Blacks serving in the Colonial Marines organized by Nicolls leaves the reader with the clear impression they were largely from Spanish and Indian masters and that they stayed in Florida, as free people when the British left.

114 The Memorial of Edward Nicolls, Major Brevet in the Royal Marines to the Honorable Lord Melville, 5 May 1817, TNA, WO 1/144, 196. On 196a he makes reference to 60 Royal Marines, 12 Marine Artillery men, 180 Indians and 252 seamen from the squadron who fought at the first attack on Fort Bower, without mentioning any involvement by Black force's. 
into slavery by $1837 .{ }^{115}$

\section{Impact of the American Blacks' Flight from Slavery on America}

The American Blacks' run from slavery had significant impacts on the Americans. While the local British commanders' instructions forbade creating a slave revolt the threat of such a thing terrorized the Americans from Maryland south. ${ }^{116}$ The local militias mounted patrols to suppress the running and intimidate any Blacks trying to plan an insurrection. ${ }^{117}$ American militias patrolled the shoreline, removing boats and canoes from the water's edge. ${ }^{118}$ Margaret Smith wrote after the attack on Washington of the good behaviour of slaves who stayed thus sparing her of the "one evil and the one I had most dread," a slave uprising. ${ }^{119}$ In the area around New Orleans the fresh memory of the slave insurrection of 1811 coupled with fears of the British provoking another pervaded the region from the outbreak of the war right through to the final departure of the British Army after their defeat in January $1815 .{ }^{120}$ General Andrew Jackson seized Pensacola from Nicolls and his allies in November 1814 mainly out of fear of the British provoking a mass exodus of slaves from the New Orleans area, if not a slave rebellion. ${ }^{121}$ The persistence of this fear would frustrate Jackson during his preparations to defend New Orleans as the local whites used the militia to hunt down runaway slaves and patrol

115 Andrew Jackson led the first efforts to seize the East portion of Florida and recapture slaves in 1817 and 1819. Florida was ceded to the United States by Spain in 1819, after which the Americans pursued the remaining ex-slaves throughout the state until all were captured or killed. See, Canter Brown Jr., “The 'Sarrazota, or Runaway Negro Plantations': Tampa Bay's First Black Community, 1812-1821," Tampa Bay History 12 no. 2 (1990): 5-19; Mark F. Boyd, "Events at Prospect Bluff on the Apalachicola River, 1808-1818," The Florida Historical Quarterly 16 no. 2 (October, 1937): 55-96; Kenneth W. Porter, "Notes on Seminole Negroes in the Bahamas," The Florida Historical Quarterly 24 no. 1 (July, 1945): 56-60; John M. Goggin, "The Seminole Negroes of Andros Island, Bahamas," The Florida Historical Quarterly 24 no. 3 (January, 1946): 201-206.

116 Harvey Wish, "The American Slave Insurrection Before 1861," The Journal of Negro History 22 no. 3 (July 1937): 299-320, see 312.

117 Grant, 266.

118 Cockburn to Cochrane, 10 May 1814, Crawford. The Naval War of 1812: Vol. III, 63-66.

119 M. B. Smith to Kirkpatrick, 11 September 1814 in Margaret Bayard Smith, The First Forty Years of Washington Society in the Family Letters of M. B. Smith (Gillard, NY: Frederick Ungar Publishing, 1906), 118-119. In an earlier letter to Maria Kirkpatrick Margaret stated that wherever there were slaves was fear of insurrection, 20 July 1813, p. 90.

120 Peter Kastor, “'Motives of Peculiar Urgency': Local Diplomacy in Louisiana, 1803-1821,” The William and Mary Quarterly, Third Series 58 no. 4(October, 2001): 819-848, see 843845. Owsley, 18 and 39-40. Local Louisiana military officers were reminded to be vigilant to signs of an insurrection in September 1813, see La Neuville to Villeré, 12 September 1813, WRC, Mss 14, and again in the summer of 1814, see unknown to Villeré, 12 August 1814, ibid. For the 1811 slave insurrection see Nathan A. Buman, "To Kill Whites: The 1811 Louisiana Slave Insurrection" (MA thesis, Department of History, B. A. Iowa State University, 2008).

121 Millett, 252-253. 
for signs of rebellion. ${ }^{122}$ The British presence off Cumberland Island forced local troops to remain in the area to try to prevent their slaves from running to the British or entering into revolt. ${ }^{123}$ Thus, apart from defending against the British raids along their coast, American troops that could have gone north to invade Canada were held in the lower states to guard their slaves.

Beyond the threat of insurrection the running of slaves delivered a direct assault on the local economy, with slave owners losing their "capital investment" not to mention the work performed by the slaves. The Virginia State General Assembly passed "An Act to perpetuate evidence of the desertion of slaves to the Enemy and for other purposes", on 10 January $1814 .{ }^{124}$ This allowed the taking of depositions, collecting evidence and valuation of slaves absconding to the British in anticipation of future compensation for the losses experienced by the slave owners. It was not just the slaves who ran, but also the threat of others fleeing that caused dislocation of the economy. One contemporary claimed that $\$ 3$ million of tobacco was at stake and nearly 1,000 slaves ready to run or rise up along the Upper Patuxent River in Maryland, in August 1814. ${ }^{125}$

In some cases owners chained their slaves to trees to keep them from running when the British landed. ${ }^{126}$ As the slave running escalated some slave owners along the coast moved their slaves inland away from access to the British. This disrupted work and, depending on which time of the year and what crop was in the field, could lead to economic ruin for the slave owner. As the war progressed local authority took stronger steps to dissuade slaves from running. The legislature of Virginia enacted harsh punishment for any slave found "eloping to His Majesty's Ships...," including the penalties of transportation and execution. In response Rear-Admiral Cockburn temporarily stopped the courtesy of allowing slave owners aboard ship to persuade their runaways to return to captivity. ${ }^{127}$

\section{British Response to the American Blacks}

The response to the American Blacks entering Nova Scotia is elegantly told elsewhere and space does not allow a great deal of detail here. ${ }^{128}$ Most of that writing focuses on the period after the war, especially 1815-18 when 1,619 more Blacks entered

122 Kastor, 844; Sugden, 252.

123 See, MacIntosh to Blackshear, 19 December 1814, MacIntosh to Blackshear, 9 January 1815, and Early to Blackshear, 19 January 1815, in Stephen Miller, ed., Memoir of General David Blackshear (Philadelphia: J. B. Lippincott \& Co., 1858), 429-430, 440-442, 448-449 respectively.

124 This act is the bases for the claims from Virginia, an example appears in Domestic Claims, NARA, Box 5, Claim 413 Daniel Carmichael.

125 Barney to Jones, 1 August 1814. Crawford. The Naval War of 1812: Vol. III, 181-183. Commodore Barney referred to Nottingham, Upper Marlborough and Queen Ann's counties.

126 Barrie to Cockburn, 7 December 1814, Crawford. The Naval War of 1812: Vol. III, 341-344.

127 Cockburn to Warren, 26 March 1814, ibid., 40-42.

128 See note 2 above. The present author recommends H. A. Whitfield's work as providing the most complete history of the Black Americans' experience in Nova Scotia. 
the colony and nearly 400 were sent to New Brunswick. This story is rather negative, filled with hardship and racism, although the survival and development of a life in Canada by the ex-slaves is a remarkable story of perseverance. As noted above the American Blacks began arriving in Nova Scotia by July 1813 (if not earlier).The initial response by colonial officials to the appearance of the Black refugees was positive as they eased a war generated labour shortage. But their rising numbers quickly wore out the welcome. Large groups of refugees were put ashore from the squadron in late 1813 and throughout 1814. ${ }^{129}$ Local officials demanded that all Blacks entering Nova Scotia be registered in Halifax. Governor Sherbrooke reiterated the process to Cochrane in October 1814, stating that Rear-Admiral Griffith (stationed in Halifax) had the refugees registered before being landed. In September, while Griffith was away invading Maine, a large number of unregistered Blacks were sent ashore at Halifax, ${ }^{130}$ and their sudden appearance alarmed the locals.

One destination for the American Blacks which has not yet been investigated was Britain. Some of those who served as servants to army and naval officers, or who entered army regiments appear to have returned to Britain with their officers or regiment. Sixteen year old Toby, who (as we learned earlier) had fled the Bowies as the British left Washington, found employment as an unnamed officer's servant, returned with the officer to London and settled there. ${ }^{131}$ Writing his parents in 1819 he seemed to be doing well, with a protector named Walker who fed, clothed and housed him when Toby was out of work. He adopted the last name Forester, possibly the name of his officer. With the absence of knowledge of numbers, or what their situation was upon arrival in Britain it is impossible to say how well they did, or how they were received; though Toby leaves us with a favourable glimpse.

The response at Bermuda was not positive, although John Weiss suggests the Black refugees working in the dockyard were welcomed at least by the navy who were short of labourers, if not the island's whites. American Blacks destined to work in the naval yard began arriving in Bermuda by early May 1813. HM Transport Ruby deposited 10 escaped slaves to the dockyard on the $14^{\text {th }}$, seven more on June $21 .{ }^{132}$ By year's end 210 American Black men and three boys from the Ruby's muster table had been 'checkered to the dockyard' as labourers. All escaped American slaves were ordered to remain on Ireland Island, within the naval yard and to work there at the same rate of pay and under similar work rules as local Blacks. Women and children were added as workers, (to be employed at picking oakum) in August 1813, as their numbers multiplied beyond expectation.

129 The 138 men women and children mentioned above who were sent ashore in September 1813 were probably the first large group and their number is what made them noticeable to the press. Similar groups were sent north from Bermuda in 1814, see note 142, below.

130 Sherbrooke to Cochrane., 7 October 1814, NLS, Sir A. Cochrane Papers, MS 2326.

131 Forester to "Farther and Mother," 5 January 1819, Domestic Claims, NARA, Box 8, Claim 752 by Charles and Ursula Bowie.

132 See Muster Table of HMT Ruby, January to March 1814, TNA, ADM 37/5140, Supernumeraries for Wages and Victuals, entries 1833-1842. 
The Colony's Regulations prohibited any Free Black from entering and settling in Bermuda. In August 1813 a special committee of the Bermuda House of Assembly and the Legislative Council suggested that "the importation of American Negroes into these Islands in his Majesty's ships, was likely to be attended with the most mischievous effects to this Colony". ${ }^{133}$ They recommended that His Excellency George Horsford do whatever he could to stop "the evil that was likely to result..." by recommending to London that all future American Slaves be sent to some other British colony such as Nova Scotia. The representatives' main concern was the, "effect in demoralizing our own Slaves" the "unlimited importation of Negroes (probably of the worst class)...from the coasts of America" would have. ${ }^{134}$ Horsford sent a protest off to Bathurst at the end of August, which was forwarded to the Admiralty. ${ }^{135}$ The message was also forwarded from Bermuda to Admiral Warren, who replied by sending more ex-slaves to Bermuda.

Commodore Andrew Evans, the superintendent of the navy yard at Bermuda wrote to the Lord Commissioners of the Navy in early October 1813 about the developing situation in the yard concerning the American Blacks. ${ }^{136}$ One hundred and eleven men had been placed as labourers in the Yard's books and earned two shillings per day. Their wives and children which Evans 'estimated' were between 20 and 30 in number had been living with them in the yard. At the beginning of October Rear-Admiral Cockburn ordered Evans to remove the men from the Yard Books and enter them into HMT Ruby's muster table as landsmen in the 'supernumeraries for victuals and wages' list and keep them working in the yard. This reduced both their pay and victuals. Evans made the arrangement and referred the decision to Warren in Halifax for approval. Only the men went to the Ruby as Evans decided "to keep the ship free from the women and Children" and kept them housed in the yard.

The women and children were given the same rations as the other families living in the naval yard and occasionally worked in the officers' gardens. The Commodore found that the women were not saving their rations to last the week, and both they and their children were in need of proper clothing. He offered to employ them picking oakum in exchange for pay. The pay would be held in account and their victuals would be deducted from it with any excess available to the women to purchase slops for themselves and the children. Evans wrote that "the greater part of them were inconsiderate enough to refuse" the offer and they continued to use up their ration too quickly. ${ }^{137}$

133 "Report of a conference...relative to the recent importation of a number of American Negroes...," Friday 13 August 1813, Bermuda Archives, Printed Journals of the House of Assembly, 1805-1820, 222-223, quote is from 223.

134 Ibid.

135 See Barrow to Goulburn, 30 September, 1813, TNA, CO 37/71.

136 Evans to the Lord Commissioners of the Navy, 12 October 1813, NMM, ADM 359/34A. Carr, History of Naval Establishments Bermuda, Bermuda Archives, 1864, 302-303. A handwritten history of the naval establishment at Bermuda held by the Bermuda Archives, this document incorrectly states that the American Blacks working in the yard were housed in the Ruby in February 1814. The author's first name is unknown.

137 Evans to the Lord Commissioners of the Navy, 12 October 1813, NMM, ADM 359/34A. 
A major concern for Commodore Evans was the wages paid to the free American Blacks. Work to repair the Roadstead at Bermuda, plus a general abundance of construction across the island was quickly driving up the wages of labourers. The two shillings four pence per day paid to his regular labourers was significantly less than the one dollar a day paid to the island slave labourers. He was afraid that his Bermudan workforce in the navy yard would quit for the civilian workforce leaving him with only the 100 American Blacks. If the American Blacks knew of the difference in pay he felt they would desert leaving him entirely without workers and causing problems from the local authorities who did not want them outside of the naval yard. ${ }^{138}$ In February 1814 Hotham (as captain of the Fleet) ordered Evans to pay the American Blacks working in the yard five shilling sterling per day and provide them with a daily allowance of spirits. ${ }^{139}$ The American Blacks did learn of the difference between their pay and that of the local labourers and complained to the British. In March, Hotham ordered the payment of arrears owed the ex-slaves employed in the yard at the February $4^{\text {th }}$ rate of pay and the granting of full victuals for the men. ${ }^{140} \mathrm{He}$ reminded Evans that they needed to pay for their slops.

The tensions among the Bermuda Whites over the presence of the American Blacks persisted and ultimately found their way to Vice-Admiral Cochrane, once he took command. In early April 1814 the Blacks not working in the yard were "becoming... troublesome \& wanting to go to Halifax." ${ }^{141}$ At the end of the month Cochrane issued an order forbidding any American Blacks from being sent to Bermuda unless they agreed to work in the naval yard for a term of five years, or if they entered the Colonial Marines. Those not wanting to work in the yard or serve in His Majesty's Sea or Land Service, as well as their families and any unattached women and children were sent to Halifax. HMS Rattler, Arab, Canso and Ramillies carried "dozens of families" north to Halifax landing them there in early May. ${ }^{142}$

The experience for the Black refugees on board the British ships was not always what might be expected of a haven. The physical conditions were extremely cramped as the ex-slaves shared the space with sailors, marines, soldiers, ship's supplies, and captured goods. Death from illness was not uncommon among the refugees who spent long periods of time (months) on board ship, but the number is unrecorded. Among the

138 The Lord Commissioners of the Navy sent the message on to Secretary Wilson of the Admiralty suggesting to pay the American Blacks the same as the other Blacks working at Bermuda. The minutes on the back of their letter indicates the discussion carried into late 1815. See Lords Commissioners of the Navy to Wilson, 11 February 1814, ibid., minutes on second page.

139 Hotham to Evans, 4 February, 1814, HHC, Hotham Collection, UDDHO 7/50.

140 Hotham to Evans, 22 March, 1814, ibid., UDDHO 7/32.

141 Cochrane to Cockburn, 28 April 1814, Crawford, The Naval War of 1812: Vol. III, 51-52.

142 While the exact number of people is not stated the phrase "dozens of families" is used in the following correspondence. See Evans to Coske, 16 April 1814, Evans to Thompson, 25 April 1814, Evans to James, 26 April 1814, all in HHC, Hotham Collection, UDDHO 7/32. Another group was sent north from Bermuda 30 April 1813, see Hotham to Masters of HMT Buffalo and Little Fredrick, 30 April 1814, ibid., UDDHO 7/33. 
Colonial Marine December 1814 was a particular bad month afloat as 28 died between the $20^{\text {th }}$ and $31^{\text {st }}$ on board HMS Regulus, victims of some contagion. ${ }^{143}$ For some females fleeing slavery the British ships were places of potential sexual exploitation. Three Black females were forcibly taken from the boats of HMS Borer by soldiers of the $85^{\text {th }}$ Regiment returning from a raid to HM Troopship Diadem. ${ }^{144}$ While the purpose of the women's removal is not discussed in the complaint made by Captain William Rawlins, he did request their return. The matter was closed with an apology for the rough handling of a sergeant from the Borer, but with no mention of the women.

Not all naval officers saw the former slaves as a wonderful addition to the British fold. Captain William Stanhope Lovell held most of the Black refugees in complete contempt, quoting them as saying, "No, me no work me free man." ${ }^{145}$ Lovell felt those with "troublesome and hard characters" ought to have been returned to Africa, to make their own way. These sentiments were shared by Commodore Andrew Evans at Bermuda who saw the Black refugees as an inconvenience, especially females, children, the old and the sick who didn't work but still consumed supplies. He considered them inclined towards laziness and "earnestly hope[d]" that resettlement would involve self-sufficiency as a "necessity." 146 Some officers even resisted taking slaves away. Historian Mary Bullard relates the story of Lieutenant John Fraser, Royal Marine Artillery, who actually discouraged slaves from leaving their masters on St. Simons Island, Georgia. ${ }^{147}$ Seen as a humanitarian by slave owners, Fraser later returned and married a local woman.

The comments of Evans and Lovell, along with Cockburn's early assessment of the Blacks smack of the era's racism. But some officers, including Robert Barrie, John Clavell, George Woodbine, Edward Nicolls and a transformed Cockburn appear to have been truly committed to the emancipation of enslaved people. They took all who came out to them, encouraged their escape, refused to return any who did not freely choose to re-enter slavery, and held them in positive regard. Nathaniel Millett's analysis of Edward Nicolls instructions to the officers leading the Blacks who joined the British service reveals Nicolls great respect for and desire to treat fairly and humanely people newly freed from slavery. ${ }^{148}$ Captain Ross commanding HMS Albion adopted a black infant, orphaned when his mother failed to return to the rendezvous point after leaving the child there. ${ }^{149}$ Ross raised the child until his own death in 1833 .

143 This number is abstracted from the Muster Table for the 3rd Battalion of Royal and Colonial Marines, 4 April to 31 December 1814, TNA, ADM 96/341.

144 Rawlins to Cochrane, 16 September 1814, NLS, Sir Alexander Cochrane Papers, MS 2331, and Harfield to Cochrane, 27 September 1814, ibid. Harfield was the master of the Diadem.

145 William Stanhope Lovell, Personal Narrative of Events From 1799 to 1815, with anecdotes (2nd ed.: London: Wm Allen and Co., 1879), 152.

146 Evans to Cockburn, 28 November 1814, Library of Congress, Sir George Cockburn Papers, v. $38,469-471$.

147 Bullard, for his dissuasion see 66, the account of his local marriage is on 59.

148 Millett, 237-240.

149 Scott, 120. 


\section{The Number and Gender of American Blacks who Escaped Slavery}

Past historians have estimated that as many as 4,000 American Blacks escaped slavery during the war. ${ }^{150}$ The American Government accepted 3,601 claims from slave owners. ${ }^{151}$ Estimates of the number of American ex-slaves that reached Nova Scotia, by 1816 , centre on the figure of 2,000, out of a generally accepted total of 3,500 escaping slavery. ${ }^{152}$ These estimates focus on slaves escaping in the areas of Chesapeake Bay and Cumberland Island.

In the previous studies the number sent to Nova Scotia was based on the belief that none arrived until September 1813 (and then only a few until the end of the war). ${ }^{153}$ They also focused on the large group (1,600 people) sent there in 1815-16. The present paper reveals that an unknown (but not insignificant) number of ex-slaves were put ashore in Halifax much earlier than previously thought, and that a substantial number were likely deposited there between April 1813 and the end of December 1814. An estimate of 2,500 going to Nova Scotia during and immediately after the war from the Chesapeake Bay area is quite probable. We can add the 371 sent to New Brunswick from Bermuda via Halifax after the war. ${ }^{154}$ John Weiss suggests just over 1000 were sent to Trinidad (most of whom were members of the Colonial Marines and their families). To this number we can add the 204 [at least] from the area around New Orleans sent to Trinidad at war's end. Added to this approximately 3,900 sub-total can be added the unknown number of former American slaves escaping into Spanish Florida, those who remained at Bermuda past 1816 and those deposited in the Bahamas and throughout the West Indies during the war. The handful taken to Great Britain after the war must be counted into the total. In addition, we need to add the unknown number of runaway slaves who died aboard the British ships and never reached British colonies, as well as those who perished attempting to reach the British. If these additional figures are set at 1,100 then an estimation of 5,000 American Blacks escaping slavery during the War of 1812 by going to the British, is easily reached.

The British refuge during the War of 1812 opened up possibilities for women and

150 Hickey, 189.

151 No. 421, Indemnities due under the award of the Emperor of Russia, for slaves and other private property carried away by the British forces in violation of the Treaty of Ghent. American State Papers Documents, Legislative and Executive, of the Congress of the United States, Class I - Foreign Relations, Second Series, Vol. 5 (Washington, 1858), 800-829.

152 Grant, 268; Spray, 64; H. A. Whitfield, “We Can Do As We Like Here': An Analysis of Self Assertion and Agency Among Black Refugees in Halifax, Nova Scotia, 1813-1821," Acadiensis 32 no. 1 (Autumn 2002): 29-49, see 33; James W. St. G. Walker, "The Establishment of a Free Black Community in Nova Scotia” in M. Kilson and R. Rotberg, eds., The African Diasporia: Interpretive Essays (Cambridge, Massachusetts: Harvard University Press, 1976), 205-236, see 228.

153 Whitfield, "The Development of Black Identity in Nova Scotia, 1813-1850," 12; Fergusson, 11.

154 Spray, 65, notes that though 400 to 500 were predicted to be sent to New Brunswick only 371 arrived. 
children (even older American Black slaves) to run which was normally not the case. Examination of Daniel Meaders' collection of advertisements concerning slaves running between March 1813 and December 1814, in Virginia reveals that 76 percent of the runaways were males (of which only three were said to be headed to the British). ${ }^{155}$ There is no definitive list of American Blacks who escaped slavery during the War of 1812. The American State Papers' list of slaves, for which named petitioners were judged eligible to receive a portion of the British compensation contains 71.6 percent males and 28.4 percent females, and makes only rare mention of children. ${ }^{156}$ This list is not able to help us in determining the number of adult women and children who fled as ages are not recorded making the determination of child or adult status impossible. An analysis of four lists, [See Table 1] each compiled at different times and places to make claims for reimbursements by the slave masters after the war, which give age (or designation as child/ren) and the sex of the person reveals that on average 62.1 percent were adult males, 21.4 percent were adult females and 16.5 percent were children (15 years of age or under). This appears to be quite different from Meaders' sample.

\begin{tabular}{|l|l|l|l|}
\hline \multicolumn{1}{|c|}{ List } & $\begin{array}{c}\text { \% Adult } \\
\text { Males }\end{array}$ & $\begin{array}{c}\text { \% Adult } \\
\text { Females }\end{array}$ & $\begin{array}{c}\text { Children (15 } \\
\text { years of age and } \\
\text { under) }\end{array}$ \\
\hline Muster Tables of British ships off Cumberland Is. & 38.0 & 28.1 & 33.9 \\
\hline Halifax List & 47.4 & 28.6 & 24.0 \\
\hline Historic New Orleans Collection Petitions & 81.9 & 17.3 & .8 (one child, unk.) \\
\hline Excerpt of Regulus Muster Table [14 March 1815] & 80.9 & 11.7 & 7.4 \\
\hline Average & 62.1 & 21.43 & 16.53 \\
\hline Boxes 5 \& 8 of RG76 Domestic Claims & 54.0 & 24.7 & 21.3 \\
\hline Average across all five sources & 60.4 & 22.8 & 17.5 \\
\hline
\end{tabular}

Table 1: Percentage of adult males and females and children across four lists of American Blacks who escaped slavery by running to the British created during the negotiations on compensating the American slave owners, and a sample from the RG76 Domestic Claims files in the United States National Archives

The percentage of women and children among the escaping slaves varies across the four contemporary lists forming Table 1 . The British documents provided to the United States to assist in determining the number of Blacks that fled slavery (including a series of excerpts from muster tables) indicate that a third of the former slaves onboard

155 Daniel Meaders, ed., Advertisements For Runaway Slaves in Virginia, 1801-1820 (New York: Garland Publishing, 1997), 190-227. Reviewing the advertisements from March 1813 through December 1814 we find 127 American Blacks ran from slavery (97 males, 26 females and 4 children) of whom 3 (all males) were said to be headed towards the British ships, the rest headed into urban centers, north or west.

156 No. 421, Indemnities...for slaves.... American State Papers Documents. 
British ships off Cumberland Island in March 1815 were children. ${ }^{157}$ The Halifax List of Blacks, another source for calculating the number of escaped slaves, with the names of those sent there from April 1815 through October 1818 has a quarter of them being children. ${ }^{158}$ The petitions from the Historic New Orleans Collection archive for the 204 slaves that left with the British after the Battle of New Orleans holds a much higher percentage of males and only one child in the group. ${ }^{159}$ The list of Colonial Marines aboard HMS Regulus, off Cumberland Island in March 1815, (also provided by the British to the Americans for determining numbers of escaped slaves) accompanied with wives and children (perhaps not all associated with the unit) also appear different from the other lists' results. ${ }^{160}$ It would seem depending where one was and the context of the moment women and children might have had greater access to fleeing. The British seized Cumberland Island and stayed there for two months, drawing in large numbers of American Blacks seeking freedom, thus women and children had a chance to get to the British positions and be safely withdrawn. At New Orleans, of the 204 who left most were from plantations which the British occupied during their assault on the city. It could be proposed in the rapid departure back to the coast, few families (only one child is listed) may have been able to join them. If we add into our overall analysis a survey of 238 of the approximately 1200 petitions for compensation made by slave owners or their estates we find more children and fewer adult males than in the other four lists (This analysis is reported on the line below "Averages across lists" in Table 1). ${ }^{161}$ The search through this sample from the claims also revealed four petitions by slave owners in New Orleans who claimed a total of 38 slaves fled with the British before or after the Battle (19 adult males, 5 adult females and 14 children), none of whom appear in the list obtained from the Historic New Orleans Collection. ${ }^{162}$ The dates for the departure of these other American Blacks from the New Orleans area do not coincide with the British retreat suggesting that the period before and after the British retreat to the Gulf coast in the New Orleans campaign allowed time and opportunity for a handful of families to escape. Even with the variation across the lists it would appear that the War of 1812 did provide Black women and children the ability to flee slavery by seeking shelter with America's enemy and more women and children took up that offer than would normally flee slavery in other directions.

157 See Documents furnished by The British Government...excerpts of muster tables of British ships off Cumberland Island early $1815,1-53,59-60$.

158 See Documents furnished by The British Government... Halifax List, 67-101.

159 Slave Evaluation Report ca1825, WRC, Mss. 199.

160 See Documents furnished by The British Government...excerpt of muster table of Regulus [14 March], 53-58.

161 Domestic Claims, NARA, of the ten boxes in the fonds, the full contents of boxes 5 and 8 were sampled.

162 Domestic Claims, NARA, see Box 8, Claims 747 by Mary Ellis and 749 by Lewis Hedge (for the same slaves which they apparently co-owned), lists 12 adult males, 4 adult females and 12 children escaping on the 10 of January 1815. Claim 748 by James W. Howard is for 7 adult males leaving on 19 February 1815, and Claim 791 by Ann Gaines' estate names an adult female and two children as leaving with the British on 8 January 1815. 


\section{Conclusions}

In conclusion, the American slaves who ran during the British war with America created an additional need [apart from the British raids] for the United States to keep troops in the southern portion of the country and thus unavailable to fight in Upper Canada. As noted earlier the departure of the slaves had an economic impact on slave owners living near the shoreline, one that is yet to be fully studied by historians. The system of slavery in the United States however was not deeply impacted by the exodus of the approximately 5000 slaves. This group represents only a tiny proportion $(1.25 \%)$ of the 400,000 slaves just in the Chesapeake area alone during that period. At the end of the war slaves who had been removed inland were simply returned. As to the individual economic loss, many slave owners applied for compensation for the slaves the British helped to escape. ${ }^{163}$

On the issue of agency, the evidence reviewed here suggests that the slaves exercised agency by running to the British before the British invited them to run and in numbers that the British were not ready to accommodate. Some may have run in the heat of the moment as the British appeared and the chaos of a raid opened the opportunity; but many came out to the British apart from these moments, gathering their family and friends, stealing boats and paddling out to the British ships at night, indicating the forethought of agency. It was for this last group clearly a conscious reflective choice to seek freedom by going to the British.

Some took the opportunity to assist the British in their fight against the Americans, either by facilitating a direct assault on a former master, acting as a guide or informant for a British raid, or enlisting in the King's Service. Approximately 19 percent of the eligible Black men among the runaway slaves joined the Colonial Marines, not the thousands of "Cossacks" predicted by Cochrane. ${ }^{164}$ Very few, if any entered the West

163 See, John B. Moore, "Chapter XI, Differences as to the Treaty of Ghent: Award of the Emperor of Russia Mixed Commissions; Domestic Commissions," History and Digest of the International Arbitrations to Which the United States has been a Party, Vol. 1 (Washington: Government Printing Office, 1898), 350-390; and Treaty of Ghent: Claims of American Citizens upon Great Britain, under the Treaty of Ghent and Convention of St. Petersburgh, for Slaves and Property captured during the War, 2 May 1825, retrieved from House of Commons Parliamentary Papers Online, 2006. The British paid \$1,204,906 to the Americans as compensation for not returning the Black Americans that ran from slavery.

164 This percentage is derived in the following manner. If the percentages of men found in the five sources listed in Table 1 (excluding the American State papers source because it does not specify children) are averaged they suggest 60 percent of the escaping American Blacks were men, or 3,000 of the estimated 5,000. A total of 372 were listed in the Muster Table for the Colonial Marine entering from 18 May through 31 December 1814. To this number we can add an estimate of 100 American Blacks who joined the Colonial Marines created by Nicolls in Florida. This creates a total of 472 who fought for the British. The 60 who appear to have been taken into the Colonial Marines from the area of Cumberland Island would increase this to 532, with the eight colonial marines at Tangier Island until March, is now 540. The 540 enlisted men would be 18 percent of total available men. For age restrictions, the British recruited men age 16 to 45 . From the two boxes of petitions sampled the number of men over 
Indies Regiment, some may have possibly joined other army regiments, some served as carpenters or sail makers for the navy and a few entered the navy as landsmen or disposable supernumeraries, but most of these last two groups would have been temporary commitments. Some may have chosen these actions as a means to seek revenge against the slave masters, or even the slave nation. Enlistment could have been used as a bargaining chip to ensure their freedom, and for some that of their family. At least half of the eligible males chose not to serve, instead simply asking for re-settlement. All of this reflects the effort to actively shape the world into which they were moving.

Agency however occurs within a context of multiple actors attempting to exert their own will on the situation and other people at hand. The British did not anticipate the number of American Blacks who ran to them from slavery and had no plan at the beginning; but they adjusted. The British created a space in which the runaway slaves could become free. By late 1813 the British began to actively encourage American slaves to run. In 1814, Cochrane's proclamation publicly offered them freedom within a British colony if they left their American masters. Yet we must remember that running to the British was only one direction in a slave's choice to flee the conditions of slavery. Throughout the war slaves ran from slavery as they had before and would after the conflict. The British may have created a space for freedom but, it was the choice of the American Black seeking escape from slavery to step into it.

Donald Hickey notes that this was, "the largest slave emancipation between 1807 and 1833." $" 165$ This might suggest that the British made a conscious effort to free enslaved people primarily for the purpose of breaking the bonds of slavery. This does not reflect the British ultimate purpose, which was to inflict the terror of a potential slave revolt, cause economic injury and contribute to the military defeat of an enemy. The ultimate example of this use of the former slaves was in the creation of the Colonial Marines. In this regard the runaway slaves were simply another tool of war in the British arsenal.

The response by British officers to the American Blacks seeking freedom was very individual and nuanced. Some American Blacks seeking refuge in the British ships were confronted with racism's ridicule, contempt and potential violence, while others met the compassionate support and protection of those opposed to slavery. The conditions aboard ship were often difficult and sometimes dangerous, yet they provided an opportunity for the Black refugees to change the course of their lives. In some ways it was a prequel to their experience in whichever colony they were settled. For those headed to Nova Scotia it was the harbinger of the hardships to come. For those sent to Trinidad it was a transition to freedom and a degree of prosperity within free Black communities on an island where slaves were in short supply.

Portions of this paper were presented in the following forums: Canadian Historical Association Annual Meeting, 30 May - 1 June 2011, Fredericton, New Brunswick; Public talk, Maritime Museum of the

45 was 21 of the 459 men, or 4.6 percent. If we remove 4.6 percent of the 3,000 we are left with 2,862 . This equals 18.9 percent of the available men joined the colonial marines. 
Atlantic, Halifax, Nova Scotia, 28 February 2012; and The War of 1812: Myth and Memory, History and Historiography, Institute for the Studies of America, London, U.K. 12-14 July 2012. The author wishes to thank members of the various audiences for their questions and comments, the comments of two anonymous reviewers and Roger Sarty, Faye Kert for information on Blacks serving aboard privateers and Alan Taylor for his comments on an earlier draft of this paper and an ongoing dialogue on this topic. 